\title{
Penilaian Kualitas Hidup Pasien Hemodialisis Rutin dengan Anemia di Yogyakarta
}

\section{The Quality of Life Assesment in Hemodialysis Patients with Anemia in Yogyakarta}

\author{
Candra Eka Puspitasari ${ }^{1,2^{*}}$, Tri Murti Andayani ${ }^{2}$, Fredie Irijanto ${ }^{3}$ \\ 1. Program Studi Farmasi, Fakultas Kedokteran Universitas Mataram \\ 2. Departemen Farmakologi Fakultas Farmasi Universitas Gadjah Mada \\ 3. Departemen Ginjal dan Dialisis Rumah Sakit Universitas Gadjah Mada \\ Submitted: 1-31-2019 Revised: 3-16-2019
}

Accepted: 9-24-2019

Korespondensi : Candra Eka Puspitasari: Email : fa.candra.eka@gmail.com

\section{ABSTRAK}

Anemia sering dialami pasien hemodialisis dan dapat berdampak pada gangguan kualitas hidup. Tujuan penelitian ini adalah untuk mengetahui pengaruh Hemoglobin $(\mathrm{Hb})$, Hematokrit $(\mathrm{Ht})$, dan karakteristik serta sosiodemografi subyek terhadap kualitas hidup. Metode yang digunakan pada penelitian ini adalah cross sectional dan teknik consecutive sampling. Pengambilan data dilakukan dengan wawancara kemudian dianalisis menggunakan regresi berganda-dummy. Kriteria inklusi antara lain pasien hemodialisis rutin dan tidak menerima transfusi darah. Uji validitas dan reliabilitas kuesioner KDQoL-SF36 menunjukkan hasil reliabel. Hasil penelitian pada 112 subyek diperoleh peningkatan kadar Hb berkorelasi positif terhadap peningkatan skor KDQoL-SF36 namun tidak bagi peningkatan kadar Ht. Peningkatan skor KDQoL-SF36 menggambarkan semakin baiknya kualitas hidup pasien. Karakteristik serta sosiodemografi yang berpengaruh terhadap kualitas hidup antara lain dummy komorbid hipertensi-diabetes dan status pekerjaan. Kondisi anemia dapat memperburuk kualitas hidup pasien hemodialisis.

Kata kunci: anemia; hemoglobin; hematokrit; kualitas hidup; KDQoL-SF36

\section{ABSTRACT}

Anemia is often experienced by hemodialysis patients and can have an impact on the quality of life. This study aims to determine the effect of hemoglobin $(\mathrm{Hb})$, hematocrit $(\mathrm{Ht})$, and the characteristics and sociodemographic of the subjects on quality of life. The method used in this study was cross sectional and consecutive sampling technique. The data is retrieved by interviews which then analyzed using dummy multiple regression. Inclusion criteria included routine hemodialysis patients and did not receive blood transfusions. The validity and reliability test of the KDQoL-SF36 questionnaire showed reliable results. The results of the study on 112 subjects obtained an increase in $\mathrm{Hb}$ levels positively correlated with an increase in the KDQoL-SF36 score but not for an increase in Ht levels. Increased KDQoL-SF36 score illustrates the better quality of life of patients. Characteristics and sociodemography that influence quality of life include comorbid dummy hypertension-diabetes and work status. The condition of anemia can worsen the quality of life for hemodialysis patients.

Keywords: anemia; hemoglobin; hematocrit; quality of life; KDQoL-SF36

\section{PENDAHULUAN}

Pasien hemodialisis umumnya mengalami anemia karena defisiensi besi dan asam folat, berkurangnya hormon eritropoetin serta hambatan eritropoesis hormon paratiroid di sumsum tulang. Kondisi ini menyebabkan penurunan kualitas hidup disertai penurunan kemampuan kognitif, seksual, toleransi aktivitas fisik serta gangguan tidur. ${ }^{1}$ Anemia dapat dinilai menggunakan parameter kadar hemoglobin $(\mathrm{Hb})$ dan hematokrit $(\mathrm{Ht})$. Terdapat perbedaan target parameter anemia tersebut pada pasien hemodialisis yaitu $\mathrm{Hb}$ minimal $11 \mathrm{~g} / \mathrm{L}^{2}$ serta $\mathrm{Hb} 10-12 \mathrm{~g} / \mathrm{dl}$ dan $\mathrm{Ht}>30 \%{ }^{3}$.

Selain anemia, faktor pemicu perubahan kualitas hidup pasien Pasien Ginjal Kronis (PGK) antara lain tekanan fisiologis maupun psikologis selama proses dialisis seperti nyeri, kelelahan, kelemahan, restriksi cairan, gatal, ketidak nyamanan, keterbatasan aktivitas fisik, biaya perawatan, dan perasaan tidak mampu. Disamping itu, perbedaan karakteristik subyek menjadi faktor tambahan yang mempengaruhi kualitas hidup ${ }^{4}$. Penelitian ini dilakukan menggunakan 
kuesioner KDQoL-SF36 yang merupakan kuesioner spesifik untuk menilai kualitas hidup pasien PGK. ${ }^{5}$ Penelitian lain yang melihat hubungan $\mathrm{Hb}$ terhadap kualitas hidup pasien PGK berdasarkan usia serta pemberian terapi anemia menunjukkan korelasi negatif pada pasien geriatri, ${ }^{6}$ sedangkan pada penelitian lainnya diketahui $\mathrm{Hb}$ memiliki hubungan yang signifikan dan parameter yang sangat berpengaruh terhadap kualitas hidup. ${ }^{7}$ Namun demikian, belum ada penelitian yang mengkombinasikan parameter lainnya yaitu hematokrit dan karakteristik pasien. Tujuan penelitian ini adalah untuk mengetahui pengaruh anemia (menggunakan parameter $\mathrm{Hb}$ dan $\mathrm{Ht}$ ) serta karakteristik subyek terhadap kualitas hidup pasien PGK.

\section{METODE}

Penelitian ini menggunakan metode cross sectional dengan teknik pengambilan sampel consecutive sampling. Setelah melalui tahap persetujuan etika dengan No.KE/FK/1/199/EC/2015 yang dikeluarkan oleh Fakultas Kedokteran Universitas Gadjah Mada, penelitian dilakukan pada bulan September 2015 hingga Januari 2016 di RS Universitas Gadjah Mada Dan RSUP Dr. Sardjito. Alat dan bahan yang digunakan adalah lembar pengumpulan data, kuesioner KDQoL-SF36, catatan medik cetak maupun online serta hasil wawancara. Penilaian kuesioner dilakukan sesuai panduan pada $A$ Manual for Use and Scoring KDQoL-SF36 yang dikembangkan oleh Research and development (RAND) Universitas Arizona. Tahap pertama penelitian yaitu dilakukan uji validitas dan reliabilitas kuesioner KDQoL-S36 menggunakan uji korelasi Pearson. Prosedur penilaian kuesioner diadopsi dari RAND dengan rentang 0 hingga 100. Semakin besar skor akhir kuesioner, menandakan semakin baik kualitas hidup pasien. ${ }^{5}$

Subyek penelitian merupakan pasien hemodialisis di kedua Rumah Sakit yang berusia $\geq 18$ tahun, menjalani hemodialisis rutin dengan frekuensi 2 kali perminggu, menggunakan eritropoetin rutin minimal dalam 3 bulan terakhir dan tidak menerima transfusi darah dalam 3 bulan terakhir. Pasien hemodialisis dengan keganasan, transplantasi ginjal, HIV/AIDS, infark miokard, gagal jantung, sirosis, demensia, stroke, dan mengalami kelumpuhan serta menjalani operasi dalam 3 bulan terakhir dikeluarkan dari penelitian. Data yang diamati adalah kadar $\mathrm{Hb}, \mathrm{Ht}$, dan karakteristik pasien. Untuk mengetahui pengaruh ketiganya terhadap kualitas hidup digunakan analisis regresi berganda-dummy menggunakan SPSS versi 19 .

\section{HASIL DAN PEMBAHASAN}

Parameter kualitas hidup makin diakui sebagai luaran terukur dalam berbagai studi terhadap dampak penyakit dan efek pengobatan pasien. ${ }^{8}$ Status kesehatan psikometri dan pengukuran utilitas merupakan dua pendekatan utama yang digunakan untuk menilai kesehatan yang berhubungan dengan luaran terapi dalam studi farmakoekonomi.

\section{Uji Validitas dan Reliabilitas Kuesioner}

Kuesioner KDQoL-SF36 merupakan jenis alat ukur spesifik untuk mengukur kualitas hidup PGK. Uji validitas dan reliabilitas dilakukan karena sebuah alat ukur memerlukan penyesuaian berdasarkan budaya, agama dan tradisi disebuah negara. ${ }^{4}$ Pada penelitian ini, dilakukan uji validitas dan reliabilitas tersendiri sebelum diaplikasikan kepada pasien dan digunakan panilaian validasi isi dan validasi konstruk dengan menggunakan nilai korelasi antara nilai tiap item pertanyaan dengan nilai total kuesioner (item to total correlation). Uji reliabilitas dilakukan untuk mengetahui konsistensi hasil pengukuran apabila dilakukan pengukuran dua kali atau lebih terhadap kondisi yang sama menggunakan alat ukur yang sama pula. ${ }^{9-11}$

Uji validitas dan reliabilitas kuesioner KDQoL-SF36 dilakukan berdasarkan pembagian item dalam 19 parameter. Pada kuesioner KDQoL-SF36, seluruh aspek reliabel dengan nilai bergerak dari $0,610-0,966$. Pada seleksi item, nilai koefisien korelasi Pearson minimal adalah 0,30 untuk 
dapat dinyatakan valid.9 Pada uji koefisien korelasi Pearson, hasil yang diperoleh pada parameter gejala problem item $14 \mathrm{~b}$ ("selama 4 minggu terakhir, seberapa berat anda terganggu oleh nyeri dada?") dan $14 \mathrm{~d}$ ("selama 4 minggu terakhir, seberapa berat anda terganggu oleh kulit gatal?"), parameter kualitas interaksi sosial item 13e ("seberapa banyak waktu anda dalam 4 minggu, merasa bisa bersahabat dengan orang lain?"), dan parameter tidur item 17 ("pada skala 0-10, bagaimana tingkat kualitas tidur selama ini?") memberikan hasil tidak valid karena nilai koefisien korelasi Pearson $<0,30$. Item lain dari kuesioner KDQoL-SF36 dinyatakan valid (0,301-0,935). Meski demikian, seluruh item tetap digunakan, karena kuesioner ini telah digunakan secara luas untuk mengukur kualitas hidup pasien PGK.

\section{Karakteristik Pasien}

Selama periode penelitian diperoleh 172 pasien, namun sebanyak 60 pasien dieksklusi disebabkan pasien mengalami keganasan (kanker, neoplasma, atau tumor), infark miokard, gagal jantung, sirosis, demensia, stroke, kelumpuhan, memiliki riwayat transplantasi ginjal dan menerima transfusi darah dalam 3 bulan terakhir. Kondisi pasien dengan riwayat infark miokard ataupun gagal jantung yang tak terkendali, infeksi berat dan kegananasan, demensia, serta adanya gangguan kognitif dan psikologis tidak diperkenankan berpartisipasi karena sangat mempengaruhi persepsi kelelahan serta depresi yang berimbas pada kualitas hidup secara keseluruhan. ${ }^{12}$ Sirosis hati pun menunjukkan timbulnya kelelahan yang disebabkan adanya neurotransmisi ke otak yang memicu pusat kelelahan menjadi aktif. ${ }^{13,14}$

Pada Tabel I, jumlah pasien laki-laki sebesar 51,3\% lebih banyak dari perempuan. Kondisi ini disebabkan pria mengkonsumsi lebih banyak protein dan memiliki massa otot yang lebih tinggi sehingga memungkinkan untuk meningkatkan kreatinin dan mempercepat progresi PGK. ${ }^{15}$ Jumlah pasien dengan kategori non-geriatrik mencapai $91,2 \%$ dengan rerata usia 50,02 $\pm 12,43$ tahun. Laporan USRDS pada tahun 2012 menyebutkan bahwa kejadian PGK meningkat pada usia 45-64 tahun dan melambat pada usia 65-74 tahun. Pada usia 4070 tahun, laju filtrasi glomerulus akan menurun secara progresif hingga $50 \%$ dari normal, terjadi penurunan kemampuan tubulus ginjal untuk merearbsorbsi dan memekatkan urin, penurunan kemampuan pengosongan kandung kemih dengan sempurna sehingga meningkatkan risiko infeksi dan obstruksi yang merupakan faktor risiko terjadinya kerusakan ginjal. ${ }^{16}$

Jumlah pasien pada penelitian ini dengan komorbid hipertensi sebesar 73,5\%. Hipertensi merupakan salah satu penyebab terjadinya PGK dan komplikasi insufisiensi ginjal, yang mana pada penelitian lain di RS PKU Muhammadiyah Yogyakarta diperoleh gambaran komorbid hipertensi sebesar $86,46 \%$, diabetes melitus sebesar $4,4 \%$, dan hipertensi-diabetes melitus sebesar $22,1 \% .{ }^{17}$ Diabetes melitus merupakan penyebab utama terjadinya gagal ginjal tahap akhir di beberapa negara di dunia. Diabetes melitus berhubungan erat dengan peningkatan risiko gagal ginjal kronik, gagal ginjal terminal, dan morbiditas kardiovaskuler. ${ }^{18}$

Semua pasien dalam penelitian ini melakukan hemodialisis sebanyak dua kali seminggu. Frekuensi hemodialisis umumnya berkisar antara 2-3 kali/minggu namun idealnya dilakukan $3 \mathrm{kali} / \mathrm{minggu}$ dengan durasi 4-5 jam. Seiring dengan pelaksanaan hemodialisis yang lebih sering dapat dilakukan kontrol anemia yang lebih baik. ${ }^{19}$ Namun demikian, hal ini belum dapat diterapkan di Indonesia, mengingat keterbatasan unit hemodialisis yang ada. ${ }^{20}$ Penggunaan eritropoetin pada 112 pasien sebesar $75,2 \%$ berjenis alfa. Penelitian 17 menyatakan sebesar $66,67 \%$ pasien menggunakan eritropoetin berjenis alfa dengan alasan kenyamanan. 
Candra Eka Puspitasari, et al

Tabel I. Karakteristik Pasien Hemodialisis disertai rerata skor KDQoL-SF36

\begin{tabular}{|c|c|c|c|}
\hline Karakteristik Subyek & $\begin{array}{c}\text { Persentase } \\
(\%)\end{array}$ & Rata-rata $\pm S D$ & $\mathbf{P}$ \\
\hline \multicolumn{4}{|l|}{ Jenis Kelamin } \\
\hline Laki-laki & 51,3 & $72,31 \pm 8,66$ & \multirow{2}{*}{$0,237 a$} \\
\hline Perempuan & 48,7 & $70,38 \pm 8,55$ & \\
\hline \multicolumn{4}{|l|}{ Usia } \\
\hline < 65 tahun (non-geriatrik) & 91,2 & $71,75 \pm 8,56$ & \multirow{2}{*}{$0,124 \mathrm{a}$} \\
\hline$\geq 65$ tahun (geriatrik) & 8,8 & $67,13 \pm 8,72$ & \\
\hline \multicolumn{4}{|l|}{ Suku } \\
\hline Jawa & 94,7 & $71,58 \pm 8,68$ & \multirow{2}{*}{$0,318^{\mathrm{a}}$} \\
\hline Luar jawa & 5,3 & $67,94 \pm 7,39$ & \\
\hline \multicolumn{4}{|l|}{ Status Pernikahan } \\
\hline Tidak Menikah & 8,8 & $69,32 \pm 7,52$ & \multirow{2}{*}{$0,432^{\mathrm{a}}$} \\
\hline Menikah & 91,2 & $71,58 \pm 8,73$ & \\
\hline \multicolumn{4}{|l|}{ Status Pekerjaan } \\
\hline Tidak bekerja & 56,6 & $74,34 \pm 7,85$ & \multirow{2}{*}{$0,001^{a}$} \\
\hline Bekerja & 43,4 & $69,08 \pm 8,55$ & \\
\hline \multicolumn{4}{|l|}{ Status Pendidikan } \\
\hline $\mathrm{SD}$ & 8,8 & $69,98 \pm 8,71$ & \multirow{4}{*}{$0,403^{\mathrm{b}}$} \\
\hline SMP & 10,6 & $75,22 \pm 6,91$ & \\
\hline SMA & 40,7 & $71,37 \pm 8,44$ & \\
\hline Perguruan Tinggi (PT) & 39,8 & $70,66 \pm 9,18$ & \\
\hline \multicolumn{4}{|l|}{ Komorbid } \\
\hline Hipertensi (HT) & 73,5 & $72,61 \pm 7,90$ & \multirow{3}{*}{$0,030^{\mathrm{b}}$} \\
\hline Diabetes Melitus (DM & 4,4 & $70,97 \pm 9,05$ & \\
\hline $\mathrm{HT}-\mathrm{DM}$ & 22,1 & $67,43 \pm 9,91$ & \\
\hline \multicolumn{4}{|l|}{ Jenis Eritropoetin } \\
\hline Alfa & 75,2 & $71,24 \pm 8,45$ & \multirow{2}{*}{$0,771^{\mathrm{a}}$} \\
\hline Beta & 24,8 & $71,79 \pm 9,28$ & \\
\hline \multicolumn{4}{|c|}{ Frekuensi Pemberian Eritropoetin } \\
\hline 1x/minggu & 31,9 & $72,88 \pm 7,27$ & \multirow{2}{*}{$0,208^{a}$} \\
\hline $2 \mathrm{x} / \mathrm{minggu}$ & 67,3 & $70,67 \pm 9,16$ & \\
\hline
\end{tabular}

Keterangan $: \mathrm{p}=$ taraf kepercayaan $5 \%(\mathrm{p}<0,05) ; \ldots{ }^{\mathrm{a}}=$ analisis menggunakan $T$-test $; . . . \mathrm{b}=$ analisis menggunakan One way-Anova; Huruf yang dicetak tebal menunjukkan adanya perbedaan yang signifikan dalam kelompok

\section{Analisis Kualitas Hidup Pasien PGK dengan Anemia}

Terdapat beragam faktor yang berpengaruh terhadap kualitas kesehatan, antara lain fungsi fisiologis, dukungan yang diperoleh, karakter individu, dan lingkungan. Faktor lain seperti efek penyakit, dinamika keluarga, kendala diet, hambatan waktu, keterbatasan fungsional, hambatan biaya, perubahan status pekerjaan, hubungan dengan karyawan, perubahan peraturan, perubahan fungsi seksual, efek pengobatan, serta kesadaran mengenai kematian juga merupakan faktor yang memperngaruhi kualitas kesehatan seseorang. Nilai rata-rata kualitas hidup pasien PGK dalam penelitian ini sebesar 71,38 $\pm 8,63$. Domain yang memiliki nilai rata-rata terendah adalah domain penyakit ginjal $(55,29 \pm 11,63)$. Parameter yang memiliki nilai rata-rata terendah adalah 
Tabel II. Rerata Skor Tiap Parameter Kuesioner KDQoL-SF36

\begin{tabular}{lc}
\hline Rerata Nilai Tiap Domain & Rata-rata \pm SD \\
\hline Kesehatan Fisik & $\mathbf{7 0 , 4 3} \pm \mathbf{1 3 , 9 8}$ \\
Status pekerjaan & $51,82 \pm 9,86$ \\
Fungsi fisik & $68,85 \pm 23,59$ \\
Peran fisik & $52,68 \pm 37,42$ \\
Nyeri & $84,02 \pm 25,56$ \\
Persepsi kesehatan umum & $70,92 \pm 19,09$ \\
Fungsi sosial & $82,70 \pm 21,36$ \\
Energi & $82,01 \pm 12,72$ \\
Kesehatan mental & $\mathbf{6 5 , 5 5} \pm \mathbf{1 2 , 9 3}$ \\
Beban penyakit ginjal & $62,96 \pm 27,77$ \\
Kualitas interaksi sosial & $12,26 \pm 16,26$ \\
Dukungan sosisl & $93,91 \pm 14,38$ \\
Kesejahteraan emosional & $88,43 \pm 11,28$ \\
Peran emosional & $70,18 \pm 39,56$ \\
Penyakit ginjal & $\mathbf{5 5 , 2 9} \pm \mathbf{1 1 , 6 3}$ \\
Gejala/prolem & $89,57 \pm 13,67$ \\
Efek penyakit ginjal & $88,74 \pm 11,19$ \\
Fungsi kognitif & $20,36 \pm 22,32$ \\
Tidur & $35,16 \pm 14,49$ \\
Fungsi seksual & $45,11 \pm 45,85$ \\
Kepuasan pasien & $\mathbf{9 3 , 7 6} \pm \mathbf{1 1 , 2 1}$ \\
Dukungan staf dialisis & $93,62 \pm 15,70$ \\
Kepuasan pasien & $43,69 \pm 29,01$ \\
\hline
\end{tabular}

parameter status pekerjaan $(51,82 \pm 9,86)$ pada domain kesehatan fisik, parameter kualitas interaksi sosial $(12,26 \pm 16,26)$ pada domain kesehatan mental, parameter fungsi kognitif $(20,36 \pm 22,32)$ pada domain penyakit ginjal dan parameter kepuasan pasien $(43,69 \pm 29,01)$ pada domain kepuasan pasien (Tabel II). Berbeda dengan penelitian sebelumnya, nilai rata-rata kualitas interaksi sosial pada pasien PGK stage 3,4, dan 5 dengan nilai $\mathrm{Hb}<11$ hingga $>13$ jauh lebih tingi yaitu sebesar 81,35 dan nilai fungsi kognitif adalah 83,95. Meskipun pada status pekerjaan nilai yang dihasilkan cukup rendah yaitu 45,20 dan pada kesehatan fisik 39,48. ${ }^{21}$

Kualitas interaksi sosial memiliki skor terendah pada penilaian kualitas hidup pasien dengan item pertanyaan pada parameter ini antara lain, "apa yang anda rasakan dan seberapa sering dirasakan dalam 4 minggu terakhir mengenai, apakah anda merasa terisolasi terhadap orang sekitar?, apakah anda lekas marah terhadap orang sekitar?, apakah anda bisa bersahabat dengan orang lain?". Dalam sesi wawancara, kebanyakan subyek mengatakan bahwa mereka enggan untuk mengikuti kegiatan sosial karena lelah, tidak mau merepotkan orang lain, maupun tidak ingin lepas kendali ketika merasa tersinggung. Beberapa penelitian yang memfokuskan pada perasaan tidak memiliki harapan, persepsi dari lepas dan hilangnya kendali, kehilangan pekerjaan, hubungan keluarga, dan hubungan sosial menyatakan bahwa pada pasien PGK perasaan hilang kendali mungkin tak terelakkan dapat terjadi. Perasaan hilang kendali ini yang menjadi prediktor kuat munculnya depresi. ${ }^{22}$

Fungsi kognitif juga menjadi parameter dengan nilai rendah, dimana item pertanyaan yang termasuk didalamnya antara lain, "apa yang anda rasakan dan seberapa sering 
dirasakan dalam 4 minggu terakhir mengenai, apakah anda merasa bereaksi lambat terhadap sesuatu yang diperintahkan atau dikerjakan orang lain?, apakah anda sulit berfikir dan berkonsentrasi?, apakah anda merasa bingung untuk melakukan sesuatu?". Penurunan fungsi kognitif dipengaruhi oleh penurunan kadar $\mathrm{Hb}$ dan $\mathrm{Ht}^{23}$

Pada uji beda kategori jenis kelamin, (Tabel I), tidak terdapat perbedaan yang bermakna pada kelompok laki-laki maupun perempuan, meskipun laki-laki $(72,31 \pm 8,66)$ memiliki nilai kualitas hidup yang lebih tinggi dibanding wanita $(70,38 \pm 8,55)$. Pada penelitian yang dilakukan Acaray dan Pinar di Turki serta Kalantar-Zadeh dkk di Amerika, menunjukkan bahwa tidak terdapat perbedaan yang signifikan pada kelompok jenis kelamin. ${ }^{24}$ Namun demikian, nilai kualitas hidup tertinggi terdapat pada kelompok subyek laki-laki dibanding perempuan. ${ }^{4,25}$

Usia merupakan salah satu prediktor utama yang menentukan kualitas fisik pasien dimana usia yang lebih muda memiliki prediksi kualitas hidup yang lebih baik. ${ }^{26}$ Begitu pula pada penelitian, ${ }^{27}$ penurunan skor kualitas hidup menurun seiring dengan pertambahan usia. Penelitian lain menunjukkan bahwa usia berdampak signifikan terhadap fungsi fisik, peran fisik, vitalitas, dan fungsi sosial, namun tidak berdampak terhadap kesehatan mental dengan menggunakan kuesioner SF36. ${ }^{4}$ Pada penelitian ini kelompok kategori usia geriatrik dan non-geriatrik tidak terdapat perbedaan kualitas hidup, meskipun demikian nilai kualitas hidup subyek non-geriatrik $(71,75 \pm$ $8,56)$ lebih tinggi dibanding subyek geriatrik $(67,13 \pm 8,72)$.

Pada uji perbedaan kelompok status pernikahan, tidak terdapat perbedaan pada kelompok menikah dan tidak menikah, namun nilai kualitas hidup subyek menikah $(71,58 \pm 8,73)$ lebih tinggi dibanding nilai kualitas hidup subyek yang tidak menikah $(69,32 \pm 7,52)$. Meski status pernikahan tidak berdampak pada kualitas hidup pasien PGK namun demikian disfungsi seksual dapat berdampak pada dinamika pernikahan dan berefek negatif terhadap hubungan pernikahan serta berimbas pada kualitas hidup. Perkembangan jangka panjang kondisi ini dapat merubah pola kehidupan dalam keluarga dan memungkinkan perubahan kemampuan kerja pasien. ${ }^{4}$

Status pekerjaan berpengaruh signifikan terhadap kualitas hidup. Subyek dengan status bekerja $(74,34 \pm 7,85)$ memiliki kualitas hidup lebih baik dibanding subyek yang tidak bekerja $(69,08 \pm 8,55)$. Subyek yang bekerja akan berinteraksi dengan banyak orang dan terbentuk suatu hubungan interaksi yang saling membutuhkan. Perasaan mendapatkan dukungan merupakan bagian dari karakter seseorang. Dukungan sosial berhubungan dengan perubahan pola pengaturan psikologis pasien hemodialisis dan depresi yang dialami diketahui merupakan efek dari minimnya hubungan sosial dengan orang lain dan perasaan sedikitnya dukungan yang diberikan. Pekerjaan dapat meminimalisir depresi pada pasien hemodialisis. ${ }^{4}$

Komorbid yang dimiliki pasien hemodialisis, terutama diabetes melitus, dapat memperburuk kualitas hidupnya. ${ }^{28}$ Pada penelitian ini, terdapat perbedaan yang signifikan terhadap kualitas hidup pada kelompok komorbid yang berbeda. Subyek dengan komorbid hipertensi-diabetes (67,43 \pm 9,91) memiliki kualitas hidup lebih rendah dibanding subyek dengan komorbid hipertensi $(72,61 \pm 7,90)$ maupun diabetes melitus $(70,97 \pm 9,05)$.

\section{Hubungan karakteristik terhadap kualitas hidup}

Analisis karakteristik terhadap kualitas hidup digunakan untuk mengetahui ada atau tidaknya pengaruh yang bersifat subyektif ${ }^{4}$, menjelaskan bahwa diperlukan penilaian mengenai budaya atau etnik, agama, jenis kelamin, usia dan beberapa variabel lainnya untuk melihat pengaruhnya terhadap kualitas hidup. Penjelasan lainnya yang menguatkan adalah karakteristik subyek dapat berpengaruh terhadap kualitas hidup penderita PGK. ${ }^{29}$ 
Tabel III. Analisis regresi berganda kualitas hidup

\begin{tabular}{lcc}
\hline Variabel & B & p \\
\hline Status Pekerjaan & $-4,482$ & 0,014 \\
Dummy Komorbid Hipertensi-Diabetes & $-4,675$ & 0,003 \\
Hemoglobin & 1,705 & 0,017 \\
\hline
\end{tabular}

Keterangan: Taraf kepercayaan $\mathrm{p}<0,05$

Tabel IV. Rerata Skor Tiap Domain Kuesioner KDQoL-SF36 pada kategori Hb

\begin{tabular}{cccccc}
\hline $\begin{array}{c}\text { Kelompok } \\
\text { Kadar } \\
\text { Hemoglobin }\end{array}$ & $\begin{array}{c}\text { Kesehatan } \\
\text { Fisik }\end{array}$ & $\begin{array}{c}\text { Kesehatan } \\
\text { Mental }\end{array}$ & $\begin{array}{c}\text { Penyakit } \\
\text { Ginjal }\end{array}$ & $\begin{array}{c}\text { Kepuasan } \\
\text { Pasien }\end{array}$ & $\begin{array}{c}\text { Kualitas } \\
\text { Hidup }\end{array}$ \\
\hline $7,0-8,0$ & $57,86 \pm 11,26$ & $65,38 \pm 11,80$ & $48,45 \pm 14,17$ & $99,11 \pm 2,36$ & $67,70 \pm 2,87$ \\
$8,1-9,0$ & $65,72 \pm 16,91$ & $62,68 \pm 14,31$ & $54,45 \pm 10,74$ & $91,78 \pm 13,69$ & $69,60 \pm 10,63$ \\
$9,1-10,0$ & $70,70 \pm 14,56$ & $65,47 \pm 13,26$ & $57,35 \pm 12,37$ & $91,66 \pm 12,36$ & $71,29 \pm 9,58$ \\
$10,1-11,0$ & $74,48 \pm 9,36$ & $65,76 \pm 13,39$ & $55,01 \pm 10,31$ & $94,56 \pm 10,32$ & $72,45 \pm 6,84$ \\
$11,1-12,0$ & $75,20 \pm 13,08$ & $69,65 \pm 9,14$ & $57,47 \pm 12,50$ & $99,31 \pm 2,08$ & $75,41 \pm 5,40$ \\
$\geq 12,1$ & $65,18 \pm 23,99$ & $73,03 \pm 1,13$ & $66,77 \pm 2,86$ & $100 \pm 0,00$ & $76,25 \pm 6,43$ \\
\hline
\end{tabular}

Hasil analisis regresi sederhana kualitas hidup menunjukkan terdapat beberapa variabel yang memenuhi persyaratan uji analisis regresi berganda dengan nilai signifikansi $\mathrm{p}>0,25$ antara lain $\mathrm{Hb}, \mathrm{Ht}$, status pekerjaan, dummy pendidikan SMP, dummy komorbid hipertensi-diabetes, jenis kelamin dan frekuensi pemberian eritropoetin. Besarnya nilai koefisien determinasi (adjusted $R$ square) seluruh variabel tersebut adalah $16,3 \%$, dengan demikian keseluruhan variabel tersebut memiliki pengaruh sebesar 16,3\% terhadap kualitas hidup. Meskipun demikian, hubungan antara variabel dependen $(y)$ dan variabel independent $(\mathrm{x})$ tersebut adalah cukup kuat yaitu 0,431, serta pada uji kelayakan model (goodness of fit) uji regresi telah memenuhi syarat signifikansi $<0,05$ yaitu nilai $\mathrm{F}=0,000$. Hasil analisis regresi berganda (Tabel III), menunjukkan bahwa hanya kategori status pekerjaan $(\mathrm{p}=0,014)$, dummy komorbid hipertensi-diabetes $(\mathrm{p}=0,003)$, dan $\mathrm{Hb} \quad(\mathrm{p}=0,017)$ yang berpengaruh terhadap kualitas hidup. Koefisien regresi merupakan besaran yang berkontribusi terhadap perubahan nilai variabel bebas dimana semakin besar nilai koefisien regresi maka kontribusi terhadap perubahan pun makin besar.

\section{Hubungan hemoglobin terhadap kualitas hidup}

Anemia berdampak negatif terhadap kadar energi dan aktivitas, perilaku makan dan tidur, status kesehatan umum, kehidupan seksual, dan dapat menyebabkan kelelahan otot, kesemutan, serta nafas pendek. Secara keseluruhan, hal tersebut berdampak pada penurunan kualitas hidup. ${ }^{4}$ Pada Tabel IV, diketahui bahwa peningkatan kadar $\mathrm{Hb}$ berpengaruh pada keempat domain kuesioner KDQoL-SF36, dimana terjadi peningkatan pada masing-masing domain. Pada rentang kadar 7,0-8,0 g/dL diperoleh skor terendah yang menunjukkan kualitas hidup terendah, sedangkan pada rentang kadar lebih dari $12,0 \mathrm{~g} / \mathrm{dL}$ diperoleh skor tertinggi yang menunjukkan tingkat kualitas hidup tertinggi. Anemia yang teratasi dapat meningkatkan kepuasan pasien, dengan peningkatan skor kualitas hidup, fungsi seksual, dan fungsi kognitif, penurunan depresi dan kemampuan bersosialisasi lebih baik. ${ }^{23}$

Berdasarkan hasil analisis regresi berganda dummy diperoleh bahwa terdapat hubungan bermakna antara peningkatan kadar $\mathrm{Hb}$ terhadap kualitas hidup $(\mathrm{p}=0,017)$ dengan nilai koefisien regresi adalah 1,705 dan konstanta adalah 63,083, 
Table V. Rerata Skor Tiap Domain Kuesioner KDQoL-SF36 pada kategori Ht

\begin{tabular}{cccccc}
\hline $\begin{array}{c}\text { Kelompok } \\
\text { Kadar } \\
\text { Hemoglobin }\end{array}$ & $\begin{array}{c}\text { Kesehatan } \\
\text { Fisik }\end{array}$ & $\begin{array}{c}\text { Kesehatan } \\
\text { Mental }\end{array}$ & $\begin{array}{c}\text { Penyakit } \\
\text { Ginjal }\end{array}$ & $\begin{array}{c}\text { Kepuasan } \\
\text { Pasien }\end{array}$ & $\begin{array}{c}\text { Kualitas } \\
\text { Hidup }\end{array}$ \\
\hline $21,0-24,9$ & $59,87 \pm 11,49$ & $62,25 \pm 12,59$ & $51,67 \pm 12,31$ & $93,90 \pm 14,86$ & $66,92 \pm 8,01$ \\
$25,0-27,9$ & $70,52 \pm 14,28$ & $66,00 \pm 13,57$ & $55,45 \pm 11,98$ & $93,16 \pm 9,87$ & $70,91 \pm 10,14$ \\
$28,0-30,9$ & $72,57 \pm 12,63$ & $64,67 \pm 13,75$ & $58,43 \pm 11,99$ & $92,67 \pm 11,72$ & $72,09 \pm 8,07$ \\
$31,0-33,9$ & $74,58 \pm 12,17$ & $66,83 \pm 12,57$ & $51,58 \pm 9,16$ & $93,98 \pm 11,98$ & $71,74 \pm 8,09$ \\
$>34,0$ & $73,44 \pm 14,21$ & $72,35 \pm 3,80$ & $61,26 \pm 10,04$ & $99,22 \pm 2,21$ & $76,57 \pm 3,78$ \\
\hline
\end{tabular}

maka diperoleh rumus regresi linier untuk peningkatan kadar $\mathrm{Hb}$ terhadap kelelahan yaitu $y=63,083+1,705 x$.

\section{Hubungan hematokrit terhadap kualitas hidup}

Terdapat penelitian di Spanyol yang menunjukkan bahwa peningkatan hematokrit dapat merubah status fungsional dan kualitas hidup (peningkatan nilai rerata hematokrit 7,5\%). ${ }^{30}$ Fungsi tidur yang lebih baik merupakan manfaat dari peningkatan nilai normal hematokrit (peningkatan nilai rerata hematokrit 10\%). ${ }^{31}$ Pada Tabel V, menunjukkan adanya perubahan pada keempat domain dengan adanya perubahan kadar Ht.

Peningkatan kadar $\mathrm{Ht}$ berdampak terhadap peningkatan skor KDQoL-SF36, yaitu pada rentang kadar 21,0-24,9\% diperoleh skor terendah yang menunjukkan tingkat kualitas hidup terendah sedangkan pada rentang kadar lebih dari 34,0\% diperoleh skor tertinggi yang menunjukkan tingkat kualitas hidup tertinggi. Meskipun demikian, berdasarkan hasil analsisi regresi berganda dummy, diketahui bahwa tidak terdapat hubungan bermakna antara peningkatan kadar $\mathrm{Ht}$ terhadap kelelahan $(\mathrm{p}=0,779)$, dengan nilai koefisien regresi adalah 0,149 dan konstanta adalah 65,498 (y=65,498 +0,149 $\mathrm{x})$.

\section{KESIMPULAN}

Penelitian ini memberikan hasil bermakna pada hubungan kadar $\mathrm{Hb}$, status pekerjaan dan komorbid hipertensi-diabetes melitus terhadap kualitas hidup $(p<0,05)$, sebaliknya pada kadar Ht diperoleh hasil tidak bermakna $(\mathrm{p}>0,05)$. Gambaran tersebut menunjukkan adanya pengaruh kondisi anemia serta karakteristik subyek PGK terhadap kualitas hidup pasien PGK.

\section{UCAPAN TERIMA KASIH}

Ucapan terima kasih kepada pembimbing utama dan pendamping yang telah memberikan masukan, kritik dan saran dalam penulisan artikel penelitian kami dan kepada Fakultas Farmasi Universitas Gadjah Mada, Yogyakarta.

\section{DAFTAR PUSTAKA}

1. Sadeghi M., Ebrahimi H., Abbasi M., Norouzadeh R. Relationship between anemia, quality of life, and laboratory indices in hemodialysis patients. Saudi J Kidney Dis Transpl. 2016;27(5):1063-1067.

2. Mikhali A., Brown C., Williams JA, et al., Clinical Practice Guideline Anaemia of Chronic Kidney Disease. Anaemia Chronic Kidney Dis. 2017;(June). www.nice.org.uk/accreditation.

3. Konsensus Manajemen Anemia Pada Pasien Gagal Ginjal Kronis. Jakarta: PERNEFRI; 2011.

4. Ayoub AMA. Quality of Life Among Dialysis Patients in United Arab Emirates. 2012.

5. Ron D. Hays., JOel D Kallich., Donna L Mapes., Stephen Joel Coons., Naseem Amin WBC and CK. Kidney Disease Quality of Life Short Form. Version 1.3. A Manual for Use and Scoring. Rand. 1997:1-39.

6. De Goeij MCM., Meuleman Y., Van Dijk S., Grootendorst DC., Dekker FW., 
Halbesma N. Haemoglobin levels and health-related quality of life in young and elderly patients on specialized predialysis care. Nephrol Dial Transplant. 2014;29(7):1391-1398.

7. Astrini WGA. Hubungan Kadar Hemoglobin, Indeks Masa Tubuh Dan Tekanan Darah Dengan Kualitas Hidup Pasien Gagal Ginjal Kronik Yang Menjalani Hemodialisis Di RSUD Dokter Soedarso Pontianak April 2013. 2013;(April):1-9.

http://jurnal.untan.ac.id/index.php/jfk/ article/view/8095.

8. Setyaningrum N. Kajian Drug-Related Problems dan Gambaran Kualitas Hidup Pasien Hemodialisis Rutin Lanjut Usia di RSUP dr. Sardjito Yogyakarta. 2013.

9. Azwar S. Reliabilitas Dan Validitas. Edisi Keti. Yogyakarta: Pustaka Pelajar; 2011.

10. Azwar S. Penyusunan Skala Psikologi. Edisi Pert. Yogyakarta: Pustaka Pelajar; 2009.

11. Siregar S. Statistik Parametrik Untuk Penelitian Kuantitatif. Jakarta: Bumi Aksara; 2013.

12. Alsén P., Brink E. Fatigue after myocardial infarction - a two-year follow-up study. J Clin Nurs. 2013;22(1112):1647-1652.

13. Artom M., Moss-Morris R., Caskey F., Chilcot J. Fatigue in advanced kidney disease. Kidney Int. 2014;86(3):497-505.

14. Henfridsson P., Bengtsson M., Hugosson I, et al. Factors Related to Fatigue in Patients With Cirrhosis Before and After Liver Transplantation. Clin Gastroenterol Hepatol. 2011;10(2):174-181.e1.

15. Neugarten J., Acharya A., Silbiger SR. Effect of Gender on the Progression of Nondiabetic Renal Disease A MetaAnalysis. J Am Soc Nephrol. 2000;11(2):319-329.

16. Brunner L., Suddarth D. Buku Ajar Keperawatan Medical Bedah. 8th ed. Jakarta: EGC; 2002.

17. Murtisiwi L. Perbandingan Kualitas
Hidup Paien Yang Menjalani Hemodialisis Dengan Terapi Epoetin Alfa Dan Epoetin Beta Di RS PKU Muhammadiyah Yogyakarta. Yogyakarta; 2015.

18. Dörhöfer L., Lammert A., Krane V., et al., Study design of DIACORE (DIAbetes COhoRtE) - a cohort study of patients with diabetes mellitus type 2 . BMC Med Genet. 2013;14:25.

19. Himmelfarb J., Ikizler TA. Hemodialysis. $N$ Engl $J$ Med. 2010;363(19):1833-1845.

20. Indonesian Renal Registry. Program Indonesian Renal Regestry (IRR). 2015:1-45.

21. Finkelstein FO., Story K., Firanek C., et al., Health-Related Quality of Life and Hemoglobin Levels in Chronic Kidney Disease Patients. Clin J Am Soc Nephrol. 2009;4(1):33-38.

22. Wang L-J., Chen C-K. The Psychological Impact of Hemodialysis on Patients with Chronic Renal Failure. 2012.

23. Kim K., Kang GW., Woo J. The quality of life of hemodialysis patients is affected not only by medical but also psychosocial factors: A canonical correlation study. J Korean Med Sci. 2018;33(14):1-11.

24. Fryar CD., Gu Q., Ogden CL., et al., Association of frailty and physical function in patients with non-dialysis CKD: a systematic review. J Ren Nutr. 2013;2(6):1. doi:10.1186/1471-2369-14228

25. Georgios T., Victoria A., Evangelos F., Savvas P., Sofia Z. Assessment of quality of life and fatigue among haemodialysis patients. Am J Nurs Sci. 2015;4(2-1):66-73.

26. Bohlke M., Nunes DL., Marini SS., Kitamura C, Andrade M, Von-Gysel MPO. Predictors of quality of life among patients on dialysis in southern Brazil. Sao Paulo Med J. 2008;126(5):252-256.

27. Lima MG., Barros MB de A., César CLG., Goldbaum M., Carandina L., Ciconelli RM. Health related quality of life among the elderly: a population- 
based study using SF-36 survey. Cad Saude Publica. 2009;25(10):2159-2167.

28. Khatib ST., Hemadneh MK., Hasan SA., Khazneh E., Zyoud SH. Quality of life in hemodialysis diabetic patients: A multicenter cross-sectional study from Palestine. BMC Nephrol. 2018;19(1):1-9.

29. Van KN., Duangpaeng S., Deenan A., Bonner A. Examining the health-related quality oflife of people $\mathrm{v}^{\wedge}$ ith end-stage kidney disease living in Hanoi, Vietnam. Ren Soc Australas J.
2012;8(3):140-145.

30. Moreno F., Sanz-Guajardo D., LopezGomez JM., Jofre R., Valderrabano F. Increasing the hematocrit has a beneficial effect on quality of life and is safe in selected hemodialysis patients. $J$ Am Soc Nephrol. 2000;11(2):335-342.

31. Parvan K., Lakdizaji S., Roshangar F., Mostofi M. Quality of sleep and its relationship to quality of life in hemodialysis patients. $J$ caring Sci. 2013;2(4):295-304. 